Article

\title{
An Approach to Digital Literacy through the Integration of Media and Information Literacy
}

\author{
Marcus Leaning \\ School of Media and Film, University of Winchester, Winchester, SO50 6AT, UK; E-Mail: marcus.leaning@winchester.ac.uk
}

Submitted: 17 December 2018 | Accepted: 25 January 2019| Published: 11 June 2019

\begin{abstract}
Digital literacy often serves as an 'umbrella' term for a range of distinct educational practices which seek to equip the user to function in digitally rich societies. This article explores two of these practices, information literacy and media literacy and through an examination of their histories and practices proposes a future direction for digital literacy. The article consists of three main sections. Section one considers the history of information literacy. The gradual development and refinement of information literacy is traced through a number of key texts and proclamations. Section two is concerned with media literacy. It is noted that media literacy education evolved in three broad strands with each pursuing differing political ends and utilising different techniques. The three approaches are still evident and differences in contemporary media education practices can be understood through this framework. The final section argues that while media and information literacy offer much there are deficiencies in both: media literacy lacks a full engagement with the nature of digital technology and how digital technology affords users new communicative practices while information literacy has not fully developed a critical approach in the way media literacy has. It is asserted that integrating and strategically revisiting both approaches offers a digitally aware and critically nuanced direction for digital literacy.
\end{abstract}

\section{Keywords}

critical digital literacy; digital literacy; history; information literacy; media literacy

\section{Issue}

This article is part of the issue "Critical Perspectives on Digital Literacies: Creating a Path Forward", edited by Hiller A. Spires (North Carolina State University, USA).

(C) 2019 by the author; licensee Cogitatio (Lisbon, Portugal). This article is licensed under a Creative Commons Attribution 4.0 International License (CC BY).

\section{Introduction}

Digital literacy refers to a broad set of competencies surrounding the use of digital media, computers and Information and Communication Technologies (ICTs). It is often understood to comprise of (or has subsumed) a number of other forms of literacy such a computer literacy, internet literacy, media literacy and information literacy. This article explores two of these component disciplines-information literacy and media literacyand considers their separate histories. It is argued that in considering how these fields have evolved and can potentially align in the future, it is possible to identify a future, critically orientated direction for digital literacy.

The article commences with a brief consideration of the idea of literacy and then moves to a consideration of the politics of information literacy and identifies a number of key moments in its history. It then turns to media literacy and education. While information literacy has developed in an approximately linear fashion with a common purpose shared by most practitioners, three distinct, historically orientated perspectives can be detected in media education and literacy and these are explored. Finally, the article contends that the two fields need to operate in concert under the auspices of media and information literacy (MIL) and that such an approach can offer a new critically orientated approach to digital literacy.

\section{Digital Literacy}

The definition of digital literacy has attracted considerable interest. As noted above, the term is generally understood to refer to a set of competencies related 
to the skilled use of computers and information technology. Paul Gilster offered a much quoted definition that digital literacy is "the ability to understand information and-more important-to evaluate and integrate information in multiple formats that the computer can deliver" (Gilster as cited in Pool, 1997, p. 6). Further, Gilster's assertion that the focus should be upon "mastering ideas, not keystrokes" (1997, p. 15) separated digital literacy from alternate, technology focused approaches and proved influential in determining the development of the field. Lankshear and Knobel $(2006,2015)$ specify the meaning further by differentiating between standardized operational approaches (where the emphasis is upon measuring discreate skills associated with the operation of computers and digital media. Jones and Hafner for example assert digital literacy relates to the engaging with the "affordances and constraints" of digital tools $(2012$, p. 13) and conceptual approaches (where the emphasis is upon developing approaches to the engagement with digital media. For example, Gilster considers digital literacy to relate to "knowledge assembly" (1997, p. 9)). As such digital literacy is considered by many not to be a single activity or set of skills but can be thought of as a range of skills. In light of the variety of foci a number of authors (for example Pangrazio, 2016) call for a reconsideration of digital literacy. One suggested way forward has been to relate digital literacy to the wider topic of literacy itself. Such approaches have sought to utilise a social theory of digital literacy (Bhatt \& McKenzie, 2019)an approach that sees literacy as realised through social practices. As such digital literacy is an aspect of literacy that explicitly considers the "practices through which people make traceable meanings using digital technologies (Gillen \& Barton, 2010, p. 1). Such an approach sees literacy as occurring across a range of settings and is developed both within and external to formal education. Buckingham (2003) for example identifies digital media as a further area to which a set of media competencies can be applied. Though such assertions are valuable and important advances in our understanding of literacy as a social and cultural activity they must be balanced with a continuing recognition that new technologies require new forms of understanding. As will be explored, digital literacy is at core a recognition that extant forms of literacy have lacked in their preparation to equip users with the skills to engage with digital technologies as such technologies present new affordances to the user. Linking digital literacy to other forms of literacy as advocates of the social theory of literacy does, relegates the digital aspect. The focus upon the social and the cultural at the expense of the technological fails to recognise the potency of digital technologies. Moreover, it ignores the significant bodies of work that have sought to accommodate and recognise the potency of technology. While the social theory of digital literacy affords a new perspective for the consideration of literacy it plays down the importance of the technological aspects of contemporary communications. Furthermore, in focussing upon the 'content' at the ex- pense of the 'form' of communications, social practice aspects ignore the extensive advances made in the fields information and media literacy in understanding digitality.

\section{Being Literate}

The equipping students with an ability to read and write in their mother tongue has been one of the central aims of mass education systems since their inception. However by the middle of the 20th century this approach to literacy began to be questioned in a number of ways. First, the interpretation that 'literacy' should refer only to textual understanding was challenged by developments in fields of communication practice other than print. For example, Dale (1946) proposed a new literacy to cover three "modes": print, audio and visual. Similarly, Debes (1968, p. 27) advocated 'visual literacy'-a set of skills to "discriminate and interpret those visible actions, objects, symbols, natural or man-made". Second, there was recognition that the increasing presence of various forms of electronic communication systems and computers from the 1970s resulted in a changed experience of the media for the viewer/user. The consequent call for multimodal literacy (Kress \& van Leeuwen, 2001) would allow the user to engage with arrange of different media forms-visual, audio, haptic and virtual reality. Third, a fear of 'falling behind' developing nations in terms of technological competency began to emerge in political discourse in a number of developed countries in the 1960s and 1970s (Belshaw, 2011). One widely proposed solution was the development of 'technological literacy' as a component of education and training programmes. For example, the Technology for All Americans paper defined the technologically literate citizen as one who has an "ability to use, manage and understand technology" (International Technology Education Association, 1996, p. 6). Aligned closely with technological literacy a further skills-based approach-computer literacy-also gained strength during the 1980s and 1990s. Many such programs were aligned with the pragmatic skills-based approach (Bawden, 2001, 2008; Lankshear \& Knobel, 2006, 2015). Such literacy programs sought (and still seek) to equip a specific group of people with a particular set of skills that will enable them to use computers.

Other literacies which emerged during the late 1980s, 1990s and 2000s included network literacy (Tyner, 1998), internet literacy (Livingstone, 2008), computer literacy (Childers, 2003) and social media literacy (Livingstone, 2014). Moving away from a focus upon a particular technology, Lankshear and Knobel's (2011) work focused upon new literacies and practices which drew upon the affordances of emergent certain social media platforms and collaborative production systems. Such approaches all offered enhancements to the previous understanding of literacy and ran parallel to the emergence of information literacy. While information literacy shared the common purpose of developing skills to deal with digital technology it differed fundamentally in that it looked 
to a specific activity rather than to a technology or platform. Information literacy is primarily concerned with the ways in which new technologies make information available and that we possess the skills to deal with information in the range of new forms. It continues and extends the focus of the bibliographic instruction courses that emerged in public libraries (Gibson, 2008) and universities (Rockman, 2004) at the start of the 20th century. As such information literacy should be understood not simply as expert use of technology but as proficiency in the use of information resources of which digital media are a very significant part.

\section{The Politics of Information Literacy}

A dominant strand in academic literature on information literacy education is that it is an unquestionable social and personal good. Research indicates that being information literate brings benefits for individual students of all ages (Batool \& Webber, 2014; Johnston \& Webber, 2003). Information literacy brings further benefits at a macro-level as means by which societies transformBruce (2004, p. 1) identifies information literacy as "the catalyst required to transform the information society of today into the learning society of tomorrow". Accordingly, information literacy is understood as benefitting both the individual and wider society and as such for the most part escapes critical interrogation (Kapitzke, 2003). Moreover, information literacy education has often been delivered in libraries and information technology departments. Beyond their contribution to education, historically such departments have not been seen as politically charged. Thus information literacy is beyond or devoid of politics. A contributing factor to this is that information education emerged from a technological if not scientific orientation; Webber and Johnston note (2000) note the close link between information literacy and information science. Information literacy has its roots in scientific rather than humanistic discourse and draws upon the technological respectability of science and technology to legitimize its place in curricula. As Escobar et al. (1994) note such practices have often escaped the same degree of scrutiny that is applied to other fields of cultural action.

\section{Key Stages in the History of Information Literacy}

There have been numerous, extensive and detailed accounts of the history and development of information literacy and the intention here will not be to repeat such accounts but to pick out high points in the development and transition of the field from its origin in the early 1970 s to its incorporation in the Media and Information Literacy Curriculum proposed by UNESCO in 2011 which is in current use at the time of writing.

The term information literacy was first used by Paul Zurkowski in a 1974 report to the US National Commission on Libraries and Information Science on the future organization priorities. Zurkowski contended that: "people trained in the application of information resources to their work can be called information literate....The work of the Commission should be viewed in terms of achieving total information literacy for the nation" (1974, pp. 6-8). As Whitworth (2014) notes, Zurkowski's definition does not develop the idea in any pedagogically useful way and situates it within a pro-liberal, managerial position identifying and advocating an environment for economic development. Following Zurkowski's work, Burchinal (1976) is considered to have advanced the field further by shifting attention to the educational aspects of information literacy (Pinto, Cordón, \& Gómez Díaz, 2010; Whitworth, 2014). Burchinal develops the idea that an information literate person possesses specific skills-specifically they are able to "efficiently and effectively locate and use information needed for problemsolving and decision-making" (1976, p. 11). Whitworth (2014) notes that while continuing the broadly liberal approach, Burchinal's work shifts the focus to instructionor more precisely education.

This approach was challenged by Hamelink (1976) who used the critical educational theories of Paolo Freire (2000) to interpret information literacy as a device with which the "cognitive costs" of contemporary society can be mitigated (Whitworth, 2014). Unfortunately, the development of such an anti-systemic, critical aspect of information literacy-an approach that constructs information literacy as something that can aid individuals rather than simply affording economic advantage to society as a whole-was not widely developed.

Perhaps the next major advance was the publication in the USA of the Presidential Committee on Information Literacy: Final Report published by the American Library Association (American Library Association [ALA], 1989). This report sought to address a concern that that US schooling lacked in developing key skills and that the US was falling behind other industrialized countries and (more problematically) developing countries would soon overtake it. A solution for such problems lays in advancing the information skills of students (Plotnick, 1999). The Report identifies a five-step process (knowing when we need information, identifying what information is needed, finding the information and evaluating it, organizing the information and using the information) to engage with information and sought to embed this in schools. A number of programmes emerged around this time and while the ALA's model was not very innovatory (similar programmes such as Eisenberg and Berkowitz's "Big6 system" (1990) also offered a granular approach) the support from the professional library community gave the final report significant credibility and resulted in the 1989 proposal by the National Forum on Information Literacy (NFIL) that information literacy become a part of main stream school education. The NFIL's report also offered a revised definition of information literacy - "the ability to access, evaluate and use information from a variety of sources" (Doyle, 1992, p. 2)-and 
identified ten discrete attributes of an information literate person.

There was also significant work on information literacy occurring outside of the USA. Bruce from Griffith's University in Australia produced the "Information Literacy Blueprint" (1994) which identified seven attributes of the information literate. This was further developed by Bruce (1997) with a phenomenological approach that challenged the overt behaviourist perspective which had previously dominated the field and marked a shift in how information literacy was understood and taught. A key text produced by the UK's Society of College, National and University Libraries (SCONUL) extended the key skills of the information literate person to include an ability to 'create' (Bent \& Stubbings, 2011). This was an important development and recognises the productive as well as the consumptive potential in digital media.

The growth in the numbers of those coming onlineby 2017 more than $80 \%$ of the population are online in over 100 countries (Sanou, 2017)-and their educational diversity drove a further revision. Information literacy became to be seen as a vital skill for those not just within the higher education sector but across wider society. International organisations, such as the United Nations Educational, Scientific and Cultural Organisation (UNESCO) coupled with international engagement by national organisations such as the US National Commission on Library and Information Science and the NFIL, sought to address such concerns at the 2003 meeting of experts in Prague. This meeting produced a revised interpretation of information literacy defining it as the ability to:

Identify, locate, evaluate, organize and effectively create, use and communicate information to address issues or problems at hand; it is a prerequisite for participating effectively in the Information Society, and is part of the basic human right of life-long learning. (UNESCO, 2003, p. 1)

The United Nations World Summit on the Information Society, which took place in Geneva in 2003 and Tunis in 2005, resulted in further description of information literacy. The Alexander Proclamation of the High Level Colloquium on Information Literacy and Lifelong Learning in $\mathbf{2 0 0 5}$ determined that information literacy "lies at the core of lifelong learning. It empowers people in all walks of life to seek, evaluate, use and create information effectively to achieve their personal, social, occupational and educational goals" (Garner, 2006, p. 3).

The simplified definition concatenates the multistage complexity of the activity in previous texts with the initial stages of recognizing a need for information being sublimated into seeking information. This reduction in the number of steps raises the comparative importance of the creative aspect. Furthermore, information literacy is regarded as an activity that 'empowers' people-it affords people the opportunity to avail themselves of information they could not get if they lacked a grounding in information literacy education. Such incorporation of the ideas of equality, rights and justice within information literacy situate it as a public 'good', information literacy is exists to advance the interest of people. As such the beneficiary of this is not the economic wealth of the nation-as was identified by Whitworth (2014) in Zurkowski's (1974) work. Instead information literacy is understood as conferring a benefit to the individual. While economic activity is still a valuable result, the foregrounded benefit is primarily one of equality and social justice.

From the mid-to-late 2000s and 2010s information literacy has begun to overlap with aspects of media literacy in terms of its content, practices and foci and there is now a strong movement towards integrating the two practices. For example, Livingstone (2008, p. 107) argues that in order to equip people "a convergence of media (or audiovisual) and information literacies is needed". Similarly Leaning $(2014,2017)$ proposes a fundamental integration of the fields. One example of this approach is the 2011 UNESCO's “Media and Information Literacy Curriculum for Teachers" (Wilson, Grizzle, Tuazon, Akyempong, \& Cheung, 2011). This curriculum offers an educational framework for the development of skills in MIL in teacher education programmes. The text establishes a direct link between MIL and democracy and overtly supports democratic practices such as the peercommunication of information between citizens. While the project is admirable in its scope it is fundamentally a media literacy project with information literacy aspects appended. It does not deal deeply enough with the digital nature of information nor fully recognise key aspects of contemporary digital culture and the use of data by organisations (Leaning, 2017).

\section{Media Literacy}

While the UNESCO MIL Curriculum articulated only a partial engagement with information literacy it also offered a specific perspective on media literacy. Historically media literacy has been used to describe a range of educational practices. Potter (2010) recognises that over 20 different definitions are in use and that there is little consensus or fixed meaning. Organisations such as the National Leadership Conference on Media Literacy (Aufderheide, 1993), the UK's Office of Communication (OFCOM, 2004) and the US based National Association for Media Literacy Education (National Association for Media Literacy Education, 2015) all offer definitions which identify a range of specific skills that a media literate person would possess. An alternative to these skills-based methods lies in an approach that looks to developing criticality in students (Silverblatt \& Eliceiri, 1997) and regards media literacy as a social and cultural practice (Sholle \& Denski, 1994). This draws upon the academic field of media studies and constructs media literacy as being able to critically engage with the media. Such approaches make use of the interpretative epistemologies found in the arts, 
humanities and social sciences as opposed to the science and technologically oriented epistemology underpinning information studies and by derivation information literacy. A number of commentators have identified distinct periods and related theoretical perspectives within this general critical tradition (Buckingham, 2003; Leaning, 2017; Masterman, 1997). While these three perspectives emerged in different historical periods they are all still evident in various contemporary media education programmes.

\subsection{The Protectionist or Inoculation Model}

The protectionist or inoculation approach is founded upon two fundamental but often unvoiced assumptions: first that media or technology can have a detrimental impact upon those who consume it. This occurs in a number of ways: it may change the values and sensibilities of a society as a whole; the media may directly impact upon the wellbeing of an individual; or the media may cause an individual to have a negative impact upon third parties. Second, there are various practices and educational techniques that can be used to negate the impact upon individuals and society-the audience can be inoculated against the media (Buckingham, 2003). This model of media education has the function of providing these practices and techniques and the resultant media literate person is 'immunised' against the negative aspects of the media.

There are many examples of the first assumption throughout the history of media technology; perhaps the first recorded example can be found in Plato's Phaedrus (Jowett, 1892, p. 77) where writing is considered problematic as: "this discovery of yours will create forgetfulness in the learners' souls, because they will not use their memories". The fear re-emerges with the invention of the printing press which drove Trithemius of Sponheim to comment "printing is no genuine friend of Holy Scripture" (Clark, 2004, p. 72). Similar concerns were raised by the philosopher Leibniz that feared the printing press would lead to the eventual elimination of scholarly arts (Klancher, 2013).

However, the origin of media education lies in the response to fears of the mass-media in late 19th and early 20th century and the emergence of a widespread, popular culture which was often blamed for many social ills. In particular, critics were explicitly concerned with the impact media would have upon the untutored minds of children and the working classes (Murdoch, 1997).

Alongside the increased newspaper circulation in the early part of the 20th century, technological advances resulted in the emergence of other mass-media forms including the phonograph, cinema, radio and television. Responses to these new media were varied; in the UK and other Western European countries a central concern was that such mass-media would result in the spread of 'alien' (read American) popular culture. Such culture was considered less intellectually demanding compared to the native 'high culture' studied in a classical European education. Accordingly, educational activities were developed to limit the negative impacts with the aim being to teach the audience to be able to discern good from bad (Masterman, 1997). The approach drew upon the literary theories of Leavis (Leavis \& Thompson, 1933) and the Modernist tradition of literary criticism and continued the Arnoldian understanding that study should focus upon high cultural texts (Arnold, 1869).

A further strand of the protectionist and defensive stance is found within the contemporaneous yet overtly Marxist work of the Frankfurt School. In this approach mass culture is understood as being central in the 'culture industry' - the means by which a working class consciousness is prevented from forming (Bennett, 1982). Mass or popular culture must be resisted as it restricts the development of awareness of class position. In spite of the radically different political agendas of the two approaches both see a common goal in resisting popular culture. Accordingly, the aim of media education is to protect the reader/viewer from the damaging impact of mass-media, to equip them with what Masterman (1997, p. 20) defines as "education against the media" (italics in original).

Despite its age (it was first developed in the 1930s) the approach is still very popular. For example, it is much in evidence in the discourses and practices of "Digital Detox" in which users willingly disengage with digital media for a period of time (Brabazon, 2012).

\subsection{The Demystification Model}

An alternate approach to media education emerged during the 1960s and by the 1980s had become the dominant academic approach in many Western countries. Drawing upon developments in various fields associated with what became known as the 'cultural' or 'linguistic' turn (the recognition of culture in explanations of human life) media educators changed the focus of their activities and rather than seeking to protect the audience now sought to empower them against problematic aspects of the media. This view identifies media content as inherently ideological-the media plays a significant role in justifying power relations to those who are most subjected to them. Accordingly, the task of media education is to make known to the audience the ideological function and methods used by the media, to 'demystify' the media to its audience (Penman \& Turnbull, 2007). The audience will then 'awaken' to this power and develop 'conscious awareness'.

The development of this approach stems from advances in theories of semiotics and ideology made in the early 1970s (Masterman, 1997). Advances in the understanding of ideology following the publication in 1971 of Gramsci's Prison Notebooks (Gramsci, Hoare, \& NowellSmith, 1971) by Hall and others (Centre for Contemporary Cultural Studies, 2007) and later Laclau, Moufee and Zizek in the field of discourse analysis (Torfing, 1999) re- 
sulted in a critique that understands ideology as present in all cultural life and continually reproduced by actors rather than being disseminated from the top by an elite. Semiotics also made major contributions to media education. The work of Barthes' (1972) is understood to have made two major contributions. First, that the media can never directly present the world to us; it can only ever offer to re-present it. The media is not a transparent lens and always mediate how we see the world. As a consequence we need to study the nature of representation in the media. Second, Barthes explicitly challenged the arbitrary distinction between high and low culture. Barthes' work contributed to a broadly left-wing classbased model of analysis that opposed the value laden conservative model of cultural appreciation which was present in the Leavisite, protectionist model.

The deployment of these practices within media education resulted in an approach that sought to empower the audience and was subsequently recognised as a form of what Kellner terms 'critical literacy' (2000). The critical aspect allows teaching to be seen as an activity that empowers students in the face of ideological forces and bestows teaching with a political function. It is still popular in many areas of media education and indeed underpins a number of contemporary media education projects such as UNESCO's MIL CLICKS campaign of information graphics (or info-graphics) that are circulated through social media. These info-graphics advocate the practices of critical literacy and alert readers to issues such as fake news and propaganda amongst others.

However, the critical approach has also been subject to criticism which draws upon earlier Leavisite ideals of culture and are consequently opposed to the idea that popular culture should be studied. A further critique of this approach to media education is that it fails to develop employment related skills. Students who take such media literacy courses are not trained in techniques that enable them to produce media content.

\subsection{The Creative Participation Model}

From the early 1990s a third approach termed the participatory or creative model incorporated developments in constructivist theory. Constructivism's roots lay in developments in psychology and pedagogy concerning the way in which learning occurs arguing that knowledge is acquired through a process of construction of knowledge in the learner's mind. Furthermore, the best way to ensure this occurs is to have the learner engage in creative and productive activities, to make a shift from a position in which knowledge is considered a discreet unit to one in which learning or knowing is seen as a process (Jones $\&$ Brader-Araje, 2002). To attend to this constructivism makes use of a range of alternative methods and teaching practices to the deconstruction of texts used in the demystification model. Typical methods used within a creative/participatory framework include: project work, collaborative media text production, group work, prac- tice by doing, structured discussion, getting students to teach each other, discovery and research work and a variety of other methods (Fernback, 2014).

In addition to this shift in general pedagogic approaches, three other developments had a significant impact upon the current shape of media education. First, the emergence then the widespread diffusion of digital technology and the impact upon the way in which media content is encountered. Second is the related change in the way audiences and media consumption are conceptualised. Buckingham (1998) notes how advances in psychology and cultural studies result in the idea of a passive audience being strongly challenged. The idea that a single homogeneous audience will receive a media text in a singular manner has been heavily criticised. In its place researchers talk of audiences who are active in the engagement with media texts. The resultant approach to media education is one in which participation and active engagement in the production of media texts play a significant role. Indeed, there has been a conscious attempt to move beyond the notion of a single author of a text and towards recognition that media content production is an inherently collaborative endeavour (Jenkins, 2009). However the extent of this treatment often tends to be rather limited. In numerous examples the analysis tends to be restricted and focused upon the extent of individual or group contribution while ignoring the impact of technological affordances and how technology plays a significant role in structuring the nature of production (Leaning, 2017).

Third, Gauntlet (2013) notes a contemporary a trend in the domestic manufacture of goods and texts. This 'maker' culture involves people in productive practices across a range of fields some traditional such as textiles and ceramics and in contemporary digital realms of production. Such a movement is both contributory to and beneficial of creative production approaches to media education.

At the time of writing the creative/participatory approach to media education is undoubtedly dominant. Its broad attention to creative and yet critical examination of media texts from a broad range of media forms allows it to inform both the critical analytic side of media studies while also being useful to the technical and industry salient areas of media training. Thus it serves as pedagogy that meets both the critical concerns of media educators and also the skills agenda of the industry advocates who challenged the demystification approach so strongly.

\section{Conclusion: Aligning Media and Information and the Value of Recognition}

This article has offered brief accounts of the history and development of the fields of information literacy and media literacy. It is argued that considering the history of educational fields has a number of distinct benefits and is valuable to the future direction of digital literacy in two 
main ways. First, in considering the history of fields it is possible to discern the main points of difference, similarity and overlap. Reviewing information and media literacy side by side reveals opportunities for integration that will allow educational practitioners to address the problems considered by information and media literacy and digital literacy from outside of the silo mentality that currently exists in which digital, information and media literacy exist as separate and distinct fields (Casey \& Brayton, 2017). This is not an argument that one field should 'colonise' another, rather that the fields, under the broad remit of digital literacy, address similar issues and combining them aids both in addressing weaknesses. Information literacy has a long history of driving users to be more skilled in their use of information and digital media. Its emphasis has been upon the manner in which information is engaged with by the user. However, in reflecting its originating discourse of information studies and its political orientation of serving a notional public good it often fails to afford a critical position. The emphasis of information literacy is to empower the user in their use of ICTs rather than to develop meta-critical skills. When information literacy does address critical skills these often tend to be those that can be used to assure the validity of process such as triangulating information and checking sources are appropriate. What information literacy does not as yet do is develop a more critically orientated perspective in terms of analysis. It does not draw upon any of the meta-critical traditions that have evolved within the humanities and social sciences for examining text and lacks the anti-conservative or progressive critical stance that informs media literacy (Kellner, 2000; Sholle \& Denski, 1994; Silverblatt \& Eliceiri, 1997).

Media literacy on the other hand has a long tradition of drawing upon the critical practices in the arts, humanities and social sciences. Much of the critical emphasis in all three approaches noted above make extensive call upon the study of cultural texts. However media literacy's approach often falls short of addressing the more technological aspects of media. Media literacy evolved and developed to engage with mass media; its focus, research methods and understanding of the impact of media evolved from an engagement with mass and broadcast media and its mode of analysis towards digital media often reflect an understanding of mass and broadcast media (Merrin, 2014). While offering high level critical skills media education for the most part does not possess techniques and understanding compatible with digital information. While some emphasis is placed upon the study of audiences within the Creative Participation model, the impact of technology and how it is used is often down played or missed (Leaning, 2017).

Second, in considering the history and practices of information and media literacy it is possible to discern the impact of technology through the educational practices developed to accommodate, engage with and mitigate the negative aspects of it. As explored above one of the key impulses for information literacy education was a perception that without developing key skills in technology (computers in particular), countries such as the US risked falling behind competitor countries in the developed and developing world. The protectionist approach to media literacy is similarly underpinned by a fear of media technology. However this is a fear of the technology and its cultural impact rather than not being adequate in the use of the technology. This understanding is important as it identifies the drive for digital literacy as originating in perceptions of problems and difficulties faced by individuals and society. Thus information and media literacy can be understood to have their origins in attempts to deal with technology. This interpretation perhaps mitigates the charge made by advocates of the "social theory of literacy" (Bhatt \& MacKenzie, 2019; Gourlay \& Oliver, 2018) that such disciplines neglect the social practices of users in lieu of understanding use through metrics. Instead it is argued that the history of information and media literacy indicates that approaches to engaging with digital media (either to acquire the skills for their user to defend or mitigate their impact) emerge from the experience of users and the fears that social practices are under threat. Recognizing the history of information and media literacy affords an understanding of such as contributory to the current practices of digital literacy; what practitioners did in the past should be considered rather than regarded as erroneous.

Accordingly it is asserted that those planning the future direction of digital literacy should be mindful of its past and the past of the constituent disciplines. Such awareness will equip us with an understanding that new synergies and assemblages of extant academic fields can benefit digital literacy and that digital literacy should be regarded as a means by which social practices and digital media can be more meaningfully understood.

\section{Conflict of Interests}

The author declares no conflict of interests.

\section{References}

American Library Association. (1989). American Library Association presidential committee on information literacy: Final report. Washington, DC: American Library Association.

Arnold, M. (1869). Culture and anarchy: An essay in political and social criticism. London: Smith, Elder \& Company.

Aufderheide, P. (1993). Media literacy. A report of the national leadership conference on media literacy. Washington, DC: ERIC.

Barthes, R., \& Lavers, A. (1972). Mythologies. New York, NY: Hill and Wang.

Batool, S., \& Webber, S. (2014). Early findings from a study of information literacy practices in primary schools of pakistan. In S. Kurbanoğlu, S. Špiranec, E. Grassian, D. Mizrachi, \& R. Catts (Eds.), Informa- 
tion literacy. Lifelong learning and digital citizenship in the 21st century (pp. 282-290). Basel: Springer International.

Bawden, D. (2001). Information and digital literacies: A review of concepts. Journal of Documentation, 57(2), 218-259.

Bawden, D. (2008). Origins and conepts of digital literacy. In C. Lankshear \& M. Knobel (Eds.), Digital literacies: concepts, policies and practices (pp. 17-32). New York, NY: Peter Lang.

Belshaw, D. (2011). What is digital literacy? A Pragmatic investigation (Unpublished doctoral dissertation). Durham University, Durham, UK.

Bennett, T. (1982). Theories of media, theories of society. In M. Gurevitch (Ed.), Culture, society and the media. London: Methuen.

Bent, M., \& Stubbings, R. (2011). The SCONUL seven pillars of information literacy. Core model for higher education. London: SCONUL.

Bhatt, I., \& Mackenzie, A. (2019). Just Google it! Digital literacy and the epistemology of ignorance. Teaching in Higher Education, 24(3), 302-317.

Brabazon, T. (2012). Time for a digital detox? From information obesity to digital dieting. Fast Capitalism. Retrieved from http://www.uta.edu/huma/ agger/fastcapitalism/9_1/brabazon9_1.html

Bruce, C. (1994). Information literacy blueprint (Unpublished). Retrieved from http://www.academia.edu/ 2463291/Information_literacy_blueprint

Bruce, C. (1997). The seven faces of information literacy. Blackwood: Auslib Press.

Bruce, C. (2004). Information literacy as a catalyst for educational change. A background paper. Paper presented at The 3rd international lifelong learning conference, Yeppoon, Queensland, Australia.

Buckingham, D. (1998). Media education in the UK: Moving beyond protectionism. Journal of Communication, 48(1), 33-43.

Buckingham, D. (2003). Media education: Literacy, learning and contemporary culture. Cambridge: Polity Press.

Burchinal, L. (1976). The communications revolution: America's third century challenge. Paper presented at The future of organizing knowledge, Texas A \& M university library's centennial academic assembly, College Station, Texas.

Casey, N., \& Brayton, S. (2017). No silos-In defense of media \& information literacy: A mini-manifesto? Retrieved from http://www.natashacasey.com/ single-post/2017/03/14/In-Defense-of-MediaInformation-Literacy-A-Mini-Manifesto

Centre for Contemporary Cultural Studies. (2007). On ideology. Abingdon: Taylor \& Francis.

Childers, S. (2003). Computer literacy: Necessity or buzzword? Information Technology and Libraries, 22(3), 100-104.

Clark, J. (2004). Print and pre-reformation religion: The Benedictines and the press, c.1470-c.1550. In J. Crick \& A. Walsham (Eds.), The uses of script and print,
1300-1700 (pp. 74-93). Cambridge: Cambridge University Press.

Dale, E. (1946). Audiovisual methods in teaching. New York, NY: Holt, Rineheart and Winston.

Debes, J. (1968). Some foundations of visual literacy. Audio Visual Instruction, 13, 961-964.

Doyle, C. S. (1992). Outcome measures for information literacy within the national education goals of 1990. Final report to national forum on information literacy. Summary of findings. Washington, DC: ERIC.

Eisenberg, M. B., \& Berkowitz, R. E. (1990). Information problem solving: The big six skills approach to library \& information skills instruction. Washington, DC: ERIC.

Escobar, A., Hess, D., Licha, I., Sibley, W., Strathern, M., \& Sutz, J. (1994). Welcome to cyberia: Notes on the anthropology of cyberculture [and comments and reply]. Current Anthropology, 35(3), 211-231.

Fernback, J. (2014). Teaching communication and media studies: Pedagogy and practice. Abingdon: Taylor \& Francis.

Freire, P. (2000). Pedagogy of the oppressed. New York, NY: Continuum.

Garner, S. D. (2006). High-level colloquium on information literacy and lifelong learning. Retrieved from https://unesdoc.unesco.org/ark:/48223/pf000 0144820

Gauntlett, D. (2013). Making is connecting. Cambridge: Wiley.

Gibson, C. (2008). The history of information literacy. In C. Cox \& E. Lindsey (Eds.), Information literacy instructional handbook (pp. 10-25). Chicago, IL: ACRL.

Gillen, J., \& Barton, D. (2010). Digital literacies: A research briefing by the technology enhanced learning phase of the teaching and learning research programme. London: TLRP

Gilster, P. (1997). Digital literacy. New York, NY: Wiley.

Gourlay, L., \& Oliver, M. (2018). Student engagement in the digital university: Sociomaterial asemblages. New York, NY: Taylor and Francis.

Gramsci, A., Hoare, Q., \& Nowell-Smith, G. (1971). Selections from the prison notebooks of Antonio Gramsci. London: International Publishers.

Hamelink, C. (1976). An alternative to news. Journal of Communication, 26(4), 120-123.

International Technology Education Association. (1996). Technology for all Americans. Reston, VA: International Technology Education Association. Retrieved from https://scholar.lib.vt.edu/TAA/Taa_tech.pdf

Jenkins, H. (2009). Convergence culture. New York, NY: New York University Press.

Johnston, B., \& Webber, S. (2003). Information literacy in higher education: A review and case study. Studies in Higher Education, 28(3), 335-352.

Jones, G., \& Brader-Araje, L. (2002). The impact of constructivism on education: Language, discourse, and meaning. American Communication Journal, 5(2), 1-10. 
Jones, R. H., \& Hafner, C. A. (2012). Understanding digital literacies. London and New York: Routledge.

Jowett, B. (1892). The dialogues of Plato in five volumes (3rd ed.). Oxford: Oxford University.

Kapitzke, C. (2003). Information literacy: A positivist epistemology and a politics of outformation. Educational theory, 53(1), 37-53.

Kellner, D. (2000). Multiple literacies and critical pedagogies: New paradigms. In P. P. Trifonas (Ed.), Revolutionary pedagogies. Cultural politics, instituting education, and the discourse of theory (pp. 196-221). London and New York: Taylor \& Francis.

Klancher, J. (2013). Transfiguring the arts and sciences: Knowledge and cultural institutions in the romantic age. Cambridge: Cambridge University Press.

Kress, G., \& van Leeuwen, T. (2001). Multimodal discourse: The modes and media of contemporary communication. Oxford: Oxford University Press.

Lankshear, C., \& Knobel, M. (2006). Digital literacies: Policy, pedagogy and research considerations for education. Digital Kompetanse: Nordic Journal of Digital Literacy, 1(1), 12-24.

Lankshear, C, \& Knobel, M. (2011). New literacies: Everyday practices and social learning (3rd ed.). Maidenhead: Open University Press.

Lankshear, C., Knobel, M. (2015). Digital literacy and digital literacies: Policy, pedagogy and research considerations for education. Digital Kompetanse: Nordic Journal of Digital Literacy, 10, 8-20.

Leaning, M. (2014). Towards the integration of media and information literacy: A rationale for a 21st century approach. In P. Mihailidis \& B. De Abreu (Eds.), Media literacy education in action: Theoretical and pedagogical perspectives. Oxford: Routledge.

Leaning, M. (2017). Media and information literacy: An integrated approach for the 21st century. Oxford: Elsevier.

Leavis, F. R., \& Thompson, D. (1933). Culture and environment: The training of critical awareness. London: Chatto \& Windus.

Livingstone, S. (2008). Internet literacy: Young people's negotiation of new online opportunities. In T. McPherson (Ed.), Digital youth, innovation, and the unexpected (pp. 101-122). Cambridge, MA: MIT Press.

Livingstone, S. (2014). Developing social media literacy: How children learn to interpret risky opportunities on social network sites. Communications, 39(3), 283-303.

Masterman, L. (1997). A rationale for media education. In R. Kubey (Ed.), Media literacy in the information age (pp. 15-78). New Brunswick: Transaction Publishers.

Merrin, W. (2014). Media studies 2.0. Oxford: Routledge.

Murdoch, G. (1997). Reservoirs of dogma: An archaeology of popular anxiety. In M. Barker \& J. Petley (Eds.), IIl effects: The media violence debate. London:
Routledge.

National Association for Media Literacy Education. (2015). Media literacy definition. Retrieved from https://namle.net/publications/media-literacydefinitions

OFCOM. (2004). Strategies and priorities for the promotion of media literacy: A statement. London: Office of Communicatins.

Pangrazio, L. (2016) Reconceptualising critical digital literacy. Discourse: Studies in the Cultural Politics of Education, 37(2), 163-174.

Penman, R., \& Turnbull, S. (2007). Media literacy: Concepts, research and regulatory issues. Melbourne: Australian Communications and Media Authority.

Pinto, M., Cordón, J. A., \& Gómez Díaz, R. (2010). Thirty years of information literacy (1977-2007): A terminological, conceptual and statistical analysis. Journal of Librarianship and Information Science, 42(1), 3-19.

Plotnick, E. (1999). Information literacy. Eric Digests. Retrieved from http://www.ericdigests.org/1999-4/ information.htm

Pool, C. (1997). A conversation with Paul Gilster. Educational Leadership, 55(3), 6-11.

Potter, W. J. (2010). The state of media literacy. Journal of Broadcasting \& Electronic Media, 54(4), 675-696.

Rockman, I. F. (2004). Integrating information literacy into the higher education curriculum. Practical models for transformation. San Francisco, CA: JosseyBass.

Sanou, B. (2017). ICT facts and figures 2017. Geneva: ICT.

Sholle, D., \& Denski, S. (1994). Media education and the (re)production of culture. Westport, СT: Bergin \& Garvey.

Silverblatt, A., \& Eliceiri, E. M. E. (1997). Dictionary of media literacy. Westport, CT: Greenwood Press.

Torfing, J. (1999). New theories of discourse: Laclau, Mouffe and Zizek. London: Wiley.

Tyner, K. (1998). Literacy in a digital world. Mahwah, NJ: Lawrence Erlbaum Associates.

UNESCO. (2003). The Prague declaration. Towards an information literate society. Paris: UNESCO. Retrieved from http://www.unesco.org/new/fileadmin/ MULTIMEDIA/HQ/Cl/Cl/pdf/PragueDeclaration.pdf

Webber, S., \& Johnston, B. (2000). Conceptions of information literacy: New perspectives and implications. Journal of Information Science, 26(6), 381-397.

Whitworth, A. (2014). Radical information literacy: Reclaiming the political heart of the IL movement. Oxford: Elsevier Science.

Wilson, C., Grizzle, A., Tuazon, R., Akyempong, K., \& Cheung, C. (2011). Media and information literacy curriculum for teachers. Paris: UNESCO.

Zurkowski, P. G. (1974). The information service environment relationships and priorities (Related Paper No. 5). Washington, DC: National Commission on Libraries and Information Science. 


\section{About the Author}

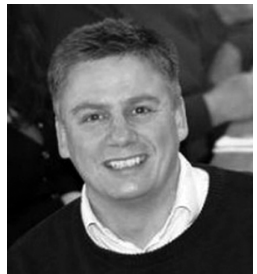

Marcus Leaning is Professor of Digital Media Education at the University of Winchester in the United Kingdom. He holds a PhD in Media Sociology, is the author or editor of seven books, has written numerous journal articles and chapters and has given academic papers in over 30 countries. He is a Fellow of the Royal Society for the Arts, a Senior Fellow of the Higher Education Academy and a National Teaching Fellow. 